\title{
外乱トルク・速度推定オブザーバ を用いた低剛性マニピュレータ制御
}

\author{
島田明*

\section{Disturbance Torque and Velocity Estimated Observer based Control System for Low-Stiffness Robot Manipulator}

\begin{abstract}
Akira SHIMADA
The aim of this paper is to clear characteristics of the obsever based robot motion controller, which observer estimates disturbance torque and velocity.

Generally, because of perturtation for moment of inertia, gravity, friction, and low-stiffness by its kinematic structures, robot motion becomes worse. It is well-known that the disturbance observer based controller is robust for not only actually disturbance but unknown perturbation. But we have never full knowledge of that observer, today.

This paper describes the phisical means of the disturbance torque and velocity estimated observer, at first. Next, it shows how the observer which is used as way of attenuation for additional disturbance, gives influence to not-nominal model. And, I will show the influence of observer and phaseshift for chaging moment of inertia. And for low stiffness manipulators, I will clear that the observer having not-optimal poles gives worse result for motion.
\end{abstract}

Key Words : Disturbance, Velocity, Observer, Low-stiffness, Control

\section{1. は じめに}

本論文は外乱トルクと運動速度とを同時に推定するオ ブザーバを用いたロボットマニピュレータ運動制御系に 関するものである.

一般にロボットの制御性を劣化させる原因には，慣性 の変動や重力の変動, 遠心力とコリオリ力の発生, 粘性 摩擦とクーロン摩擦, そして剛性の低下等があげられる.

これらの問題点に対してロボットマニピュレータの制 御性を維持するためには, マニピュレータ自身の剛性の 向上を図ると共に制御系に関しても何らかの工夫が必要 である. 本論文ではそのための工夫として，外乱トルク と速度を同時に推定するオブザーバを用いた制御系を紹 介し，その解析と有効性の実証を試みるものである.

原稿受付 1992 年 9 月 7 日

*セイコー電子工業 (株) FA システム部

日本ロボット学会誌 10 巻 7 号
一般に, 外乱オブザーバを用いた制御系は, 外力のみ でなく未知のパラメータ変動やモデルの不確かさに対し てロバストな制御系であると言われている1 3). しかし ながら, 重力やクーロン摩擦あるいは外力のように, 定 常的かつ加法的な性質を持つ外乱や，遠心力・コリオリ 力あるいは粘性摩擦のように高周波成分をあまり持たな い外乱に対する外乱オブザーバの有効性に関しては，多 くの研究事例があり有効性も示されているが, 慣性の変 動や剛性の低下のように, 伝達関数モデルが变化する場 合のオブザーバの作用と有効性については，まだ未知な 点が残っているように思われる.

本論文は上記の問題を解決することを意図している.

まず最初に，モータが発生する駆動トルクと角度位置 とを入力として, モータ軸の外乱トルクと回転速度とを 同時に推定する最小次元オブザーバを紹介する ${ }^{10)}$. その ようなオブザーバを用いて推定外乱值を直接にフィード 
バックすれば，モータ軸にかかる真の外乱はほぼ完全に 打ち消すことができるはずである.

さらに推定速度を速度フィードバックに利用すること もできる ${ }^{10,11)}$ 。この際, タコジェネレータ等の速度検出 器や F/V 变換器等の速度検出回路を必要としないこと は実用上の大きな利点である.

次に，前記のよらなオブザーバの推定機能を物理的に 解析する. すなわち，従来の多くの外乱オブザーバは入 カとして駆動トルクまたは駆動電流と，速度とを用いて きたが，本論文では速度の代わりに位置入力を用いてい る.このような方法はごく最近まで一般的ではなかっ た 10,11). 少なくとも同時に速度も推定する利点につい て触られることはなく，まして推定速度の性質について は未知であった．以上の理由により，本オブザーバの性 質を調べていく必要があるわけである.

その次に，オブザーバを用いた位置制御系を紹介し， その制御系の性質を解析する，一般に，外乱オブザーバ による推定外乱のフィードバックによって真の外乱を見 かけの上で打ち消すことは，外乱オブザーバの設計思想 そのものである ${ }^{1 \sim 3)}$. しかしそれは同時に，制御対象を 見かけの上で理想的な制御対象に強制的に加工する作用 でもある．さらに見方を変えると，それは部分的なモデ ルマッチングを行らこととも等価である.この性質を本 論文では，推定外乱をフィードバックすることにより生 じるモデルマッチング機能と呼ぶことにする．そこで, 本論文で用いるオブザーバについても，モデルマッチン グ機能を確認しておく.

最後に，その制御系を実際のロボット制御に利用した 場合の有効性を示す，初めに，慣性変動があり剛性の低 いロボットマニピュレータを対象に，ボード線罒や極零 配置を用いてオブザーバのモデルマッチング機能を検証 する．次いで制御系の外乱除去特性と追従性とを評価す るために周波数特性と運動速度の実測を行う ${ }^{14) . ~}$

\section{2. 外乱トルク・速度推定オブザーバ}

本論文では，ロボットを動力学的に各軸每に分離して 扱う。まず各軸の駆動トルクを慣性が標準值（ノミナル 值）と一致する場合の加速トルクとそれ以外の外乱トル

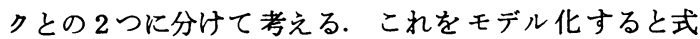
（1）のように表せる. 但し, 回転角度位固 $\theta$, 駆動トル ク $T m$, 標準慣性值 $J$, 外乱トルク $T_{L}$ とおく.

$$
T_{m}=J \ddot{\theta}+T_{L}
$$

これに対応する状態方程式として式 (2) 式 (3)を構 成すると可観測性が成立する. 従って, 最小次元オブザ 一バとして，式 (4) 式 (5) を構成することができる. 前述のように，本オブザーバは速度情報を使用せずに，
外乱トルクと速度とを同時に推定できる最小次元オブザ 一バである10).

$$
x_{1}=\theta, \quad x_{2}=\dot{\theta}, \quad x_{3}=T_{L}, \quad y=x_{1}, \quad u=T_{m}, \dot{T}_{L}=0
$$

$$
\begin{aligned}
& {\left[\begin{array}{c}
\dot{x}_{1} \\
\dot{x}_{2} \\
\dot{x}_{3}
\end{array}\right]=\left[\begin{array}{ccc}
0 & 1 & 0 \\
0 & 0 & -1 / J \\
0 & 0 & 0
\end{array}\right]\left[\begin{array}{c}
x_{1} \\
x_{2} \\
x_{3}
\end{array}\right]+\left[\begin{array}{c}
0 \\
1 / J \\
0
\end{array}\right] u} \\
& y=\left[\begin{array}{lll}
1 & 0 & 0
\end{array}\right]\left[\begin{array}{lll}
x_{1} & x_{2} & x_{3}
\end{array}\right]^{T} \\
& {\left[\begin{array}{l}
\dot{z}_{1} \\
\dot{z}_{2}
\end{array}\right]=\left[\begin{array}{cc}
-l_{1} & -1 / J \\
-l_{2} & 0
\end{array}\right]\left[\begin{array}{l}
z_{1} \\
z_{2}
\end{array}\right]} \\
& +\left[\begin{array}{cc}
-l_{1}{ }^{2}-l_{2} / J & 1 / J \\
-l_{1} l_{2} & 0
\end{array}\right]\left[\begin{array}{c}
\theta \\
T_{m}
\end{array}\right] \\
& {\left[\begin{array}{c}
\hat{\theta} \\
\hat{\theta} \\
\hat{T}_{L}
\end{array}\right]=\left[\begin{array}{ll}
0 & 0 \\
1 & 0 \\
0 & 1
\end{array}\right]\left[\begin{array}{l}
z_{1} \\
z_{2}
\end{array}\right]+\left[\begin{array}{ll}
1 & 0 \\
l_{1} & 0 \\
l_{2} & 0
\end{array}\right]\left[\begin{array}{c}
\theta \\
T_{m}
\end{array}\right]}
\end{aligned}
$$

$\hat{\theta} \cdots$ 推定速度, $\hat{T}_{L} \cdots$ 推定外乱トルク

\section{3. オブザーバの物理的意味}

本節ではオブザーバで推定した状態量の物理的な意味 について検証する。 まず，式 (4) 式 (5) を公達関数変 換すると式 (6) 式 (7) が得られる. 式 (6)をよく見 ると，本オブザーバの推定外乱トルクとは真の外乱トル クを 2 次のローパスフィルタに入力して得られた出力と 等価なるのであることがわかる.

$$
\begin{aligned}
\hat{T}_{L}= & \left\{\frac{S\left(-l_{1} l_{2}\right)+l_{2}{ }^{2} / J}{S^{2}+S l_{1}-l_{2} / J}+l_{2}\right\} \theta+\frac{-l_{2} / J}{S^{2}+S l_{1}-l_{2} / J} T_{m} \\
& =\frac{-l_{2} / J}{S^{2}+S l_{1}-l_{2} / J}\left(T_{m}-S^{2} J \theta\right) \\
& =\frac{-l_{2} / J}{S^{2}+S l_{1}-l_{2} / J} T_{L},\left(l_{1} \geqq 0, l_{2}<0\right) \quad(6)
\end{aligned}
$$

式（7）は推定された速度が真の速度の項と外乱トル クの影響を受けた項の和で表される.さらに式（8）に 見られるように，外乱が存在しない場合には遅れのない 真の速度を推定できることを意味している.

また式 (7) の右辺第 2 項は, 分母が 2 次であるのに 対して分子が 1 次項のみであることから，完全にプロパ 一なので最終值定理が使え 0 に収束するので, 定常外乱 に対して速度推定に定常誤差を持たないことがわかる. この解析結果から, 本オブザーバの速度推定機能は有效 な推定信号として利用できると考兄られる。

$$
\begin{aligned}
& \hat{\theta}=\left\{\frac{S\left(-l_{1}{ }^{2}-l_{2} / J\right)+l_{1} l_{2} / J}{S^{2}+S l_{1}-l_{2} / J}+l_{1}\right\} \theta \\
&+\frac{S / J}{S^{2}+S l_{1}-l_{2} / J} T_{m} \\
&= \frac{S\left(S l_{1}-l_{2} / J\right)}{S^{2}+S l_{1}-l_{2} / J} \theta+\frac{S^{2}}{S^{2}+S l_{1}-l_{2} / J} \frac{T_{m}}{S J} \\
&= \dot{\theta}+\frac{S / J}{S^{2}+S l_{1}-l_{2} / J} T_{L} \\
& \text { If } T_{L}=0, \hat{\theta}=\dot{\theta}
\end{aligned}
$$




\section{4. 制卸系と等価変換}

本節では前記のオブザーバを用いた位置制御系を紹介 し，その性質を解析する.

初めに位置制御系の伝達関数ブロック図を Fig. 1 に 示し，その構成について説明することにする.

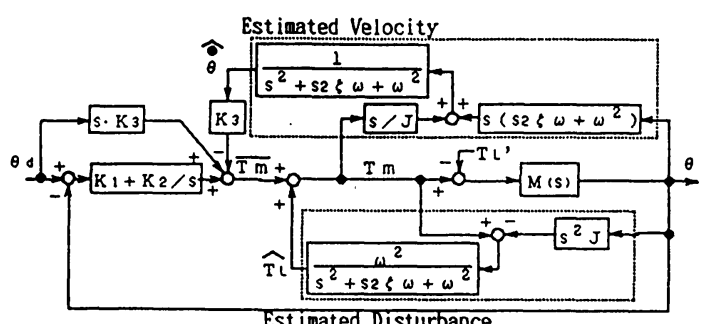

Fig. 1 Observer basd control system

Fig. 1 亿括いて, 制御対象の伝達関数を実有利関数か ら成る $M(s)$ と表すことにする.

ところで，式（1）では制御対象の運動方程式を加速 トルクと外乱トルクの和として表わした．この考えを延 長するならば, 制御対象の伝達関数を $1 / s^{2} J$ と表し, $1 / s^{2} J$ で表しきれない会達関数の誤差を全て加法的な外 乱として扱らべきである.オブザーバもそのような仮定 により設計したはずである.

しかしながら実際には，制御対象の伝達関数は必ずし も慣性と外乱のように単純化して扱えるとは限らないの ではないかと言う疑念が残る。例党ば，2慣性系で表わ されるような剛性の低い制御対象は，一般に高次の伝達 関数で表される.そのよらな場合でも前記の仮定を用い て設計した制御系では優れた制御性を発揮するだろらか，

本節ではそのような問いに対する答えを求めることを 意図し，制御対象を一般的な伝達関数 $M(s)$ として表わ し解析することにした。

次に, $T_{L^{\prime}}$ は制御対象を $M(s)$ と表現し直した際に, さらに残るモデル化誤差と新たに加わる外力とする.

図中の点線で囲まれた部分のらちの, 下側の囲いはオ ブザーバの外乱トルクを推定する部分にあたり，式（6） の第 2 行目を表わしている. 但し理解を助けるために, 一般に 2 次系を表すのに用いられる 6 と $\omega$ を使用し， $l_{1}=2 \zeta \omega, l_{2}=-J \omega^{2}$ と扰くことにした.

一方，上側の囲いはオブザーバの速度推定部分であり， 式 (7)の 3 行目を書き直したものである. 各々に対し, 式 (6) 式 (7) の最終結果を使用していないのは，実際 のオブザーバ入力である $T m$ と $\theta$ とをそのまま用いた形 で表記するためである.

さらに，推定速度をゲイン $K_{3}$ で速度フィードベック

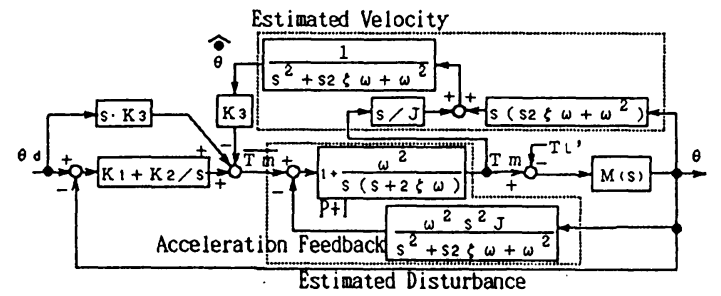

Fig. 2 Equivalent system

する. そして推定外乱トルクについては，実外乱と制御 対象のモデル誤差とを打ち消すために，十符号のままフ ィードバックする ${ }^{1 \sim 3)}$.

そして外側に, 偏差に対する比例・積分補償項と速度 に対するフィードフォワード項を付加する.

次に Fig. 1 の位置制御系のオブザーバに関して, 外乱 推定部分を等価変換すると Fig. 2 のように表せる. 点 線による围いの前向き部分は積分補償項に 1 次遅れ系を 乗じて，さらに比例成分 1 を加えた形である．これは外 側ループの比例積分補償項とは別に内側にもう 1 つの比 例積分補償項が存在することを意味している.

また，囲いの後ろ向き部分は位置の 2 階微分に 2 次の ローパスフィルタを乗じた形で表されているが，これは 高周波ノイズを減衰させた加速度フィードバック補償と 等価であると解釈できる．また加速度フィードバックゲ

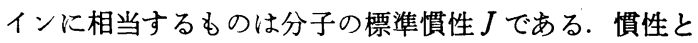
加速度の乗算は加速トルクを意味するので，このフィー ドバックは標準慣性に対する加速トルクフィードバック と解釈することも可能である.

以上を併せて考觉ると以下のように説明できる.

前向き部分の比例積分項の働きは, 内側のループヘの 入力 $\overline{T m}$ と前記の加速トルクフィードバックとの誤差を 0にするようにループ内の外乱を除去する働きをする. そしてこの誤差が常に0に収束されるのであれば, $\overline{T m}$ の值としていつでも標準慣性負荷を駆動するのに必要な トルク值を使用すれば良い，すなわち，内側のループヘ の入力 $\overline{T m}$ から見た出力 $\theta$ までの伝達関数は, 標準慣性 に対する伝達関数 $1 / s^{2} J$ に等しくなるはずである.

これを本論文では, 外乱オブザーバのフィードバック によるモデルマッチング機能と呼んでいる.

以上の等価変換による解析は, 速度を入力とする外乱. オブザーバに関しては既に行われている．本論文では位 置情報を入力とするオブザーバに関して解析を行ったも のである.

次の Fig. 3 は, 前記のモデルマッチング機能を別の 角度から検討するために，Fig. 2 の制御系をさらに等価 変換したものである. 具体的には，Fig. 2 の Tmから $\theta$ までの伝達関数と $\theta$ から $\hat{\theta}$ までの伝達関数を描き直した 


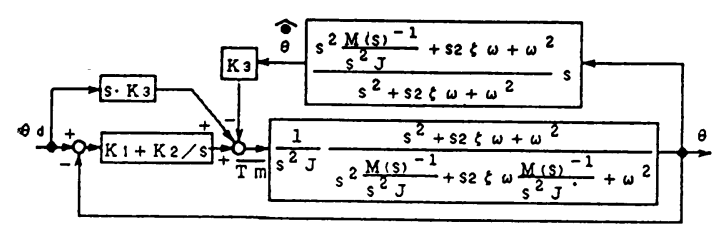

Fig. 3 Equivalent system 2

ものであり，制御対象の伝達関数の変化が与える影響を 直感的で見やすい形にしたものである．例えば制御対象 が標準慣性のみからなる場合は， $M(s)=1 / s^{2} J$ なので $\overline{T m}$ から $\theta$ までは $1 / s^{2} J$ になり， $\theta$ から $\theta$ までは微分伝 達関数 $s$ のみなる. しかし慣性が標準慣性からずれる 場合には, 各々にとって分母が 2 次, 分子も 2 次でしか も極零が異なる伀達関数を直列に挿入したことになる. また $M(s)$ が慣性以外の高次特性を持つ場合は, 次数の 異なる伝達関数要素を各々に直列に挿入することを示し ている.

この影響の大きさは, $M(s)$ の $1 / s^{2} J$ との䛊差とオブ ザーバのパラメータ $\boldsymbol{と} \omega$ との関係で決まり，それがモ デルマッチング機能や安定性に制限を与えるであろうこ とを Fig. 3 から予想できるのではないかと思われる.

補足として，これまで $M(s)$ は央有理関数としか定め ていない、そのため制御系全体の安定性はまだ保証され ていないことにも留意しておく必要がある.

式 (9) 式 (10) は Fig. 2 から求めた制御系の伝達関 数である. 直前に紹介した Fig. 3から導出しないのは,

Fig. 3 が $T_{L}{ }^{\prime}$ を無視して表現しているためである. 後に シミュレーション等に用いるため, 制御系ブロック図に 続けて本節で紹介しておく，係数の独特の定義は解析の ために便宜上決めたものである.

$$
\begin{aligned}
& \frac{\theta}{\theta_{d}}=\frac{s^{4} B_{1}+s^{3} B_{2}+s^{2} B_{3}+s B_{4}+B_{5}}{s^{5} A_{1}+s^{4} A_{2}+s^{3} A_{3}+s^{2} A_{4}+s A_{5}+A_{6}} \\
& \frac{\theta}{T_{L}^{\prime}}=\frac{-s^{2}\left\{s+\left(J 2 \zeta \omega+K_{3}\right) / J\right\}}{s^{5} A_{1}+s^{4} A_{2}+s^{3} A_{3}+s^{2} A_{4}+s A_{5}+A_{6}} \\
& A_{1}=\frac{M(s)^{-1}}{s^{2} J} J \quad A_{2}=\frac{M(s)^{-1}}{s^{2} J}\left(J 2 \zeta \omega+K_{3}\right) \\
& A_{3}=J \omega^{2}+K_{1}+K_{3} 2 \zeta \omega \quad B_{1}=K_{3} \\
& A_{4}=B_{3}=K_{1} 2 \zeta \omega+K_{2}+K_{3} \omega^{2} \quad B_{2}=K_{1}+K_{3} 2 \zeta \omega \\
& A_{5}=B_{4}=K_{1} \omega^{2}+K_{2} 2 \zeta \omega \quad A_{6}=B_{5}=K_{2} \omega^{2}
\end{aligned}
$$

\section{5. 惯性の变動}

本節ではロボットが未知の慣性変動を起こす場合の, オブザーバの作用について考察を行う，そこでまず，慣 性が 1/10 倍と 10 倍に変化した場合の Fig. 3 における $\theta / \overline{T m}$ の特性を Fig. 4,5 に表す.

なお，Fig. 4 と 5 のボード線図はゲインと位相とを見 分けにくい点もあるが，使用ソフトの構成上やむを得な

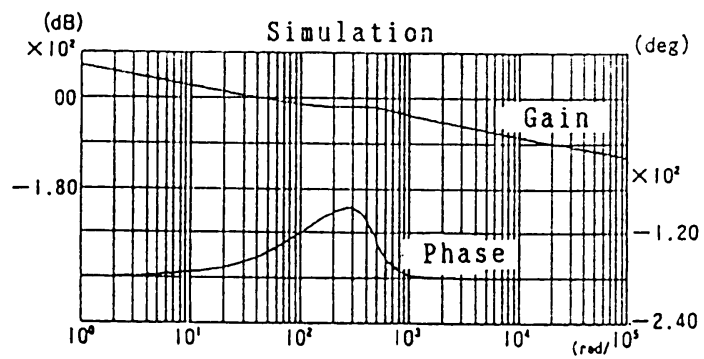

Fig. 4 Bode diagram at $1 / 10$

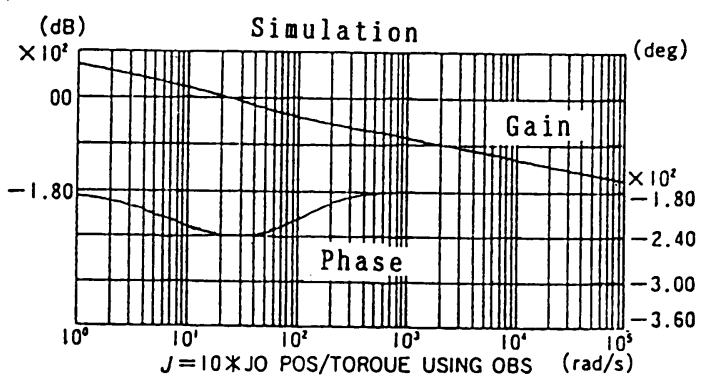

Fig. 5 Bote diagram at 10

いので御了承いただきたい，上半がゲインを表し，左側 に $\mathrm{dB}$ の目盛りを $100 \mathrm{~dB}$ 単位で表記している. 下半は 位相で，右側に度の目盛りを表記している.

さて, 図の特徵について説明すると以下のようになる.

1）低周波領域では，変化した慣性が標準慣性による 特性と等しくなるよらにオブザーバが作用している.す なわち，Fig. 4 ではオブザーバがなければ，高周波領域 に見られる直線上のゲインを低周波域にそのまま延長す るところまでゲインが上がるはずだが，オブザーバによ り下方に平行移動しているわけである. Fig. 5 では逆に 上方に移動している.

2）高周波領域ではオブザーバの作用が及ぼないため に, 特性の変化がそのまま現れる.すなわち慣性変動に 従い,ゲインが各々上下に平行移動する.

3）中間の周波数領域では, ゲインは 1）2）をつなぐ 状態にあるが, 位相は大きく変化する.

以上の検討により，制御対象の慣性変動に対するオブ ザーバの作用を周波数領域で直接に見ることができた.

さて外乱オブザーバの補償は慣性の変動に対して位相 変化を伴らことがわかった．そこで比較のため，この位 相変化に着目し，他の制御法を検討しておくことにする。

対象として計算トルク法から派生して提案される分解 加速度制御を考兵る. 分解加速度制御では重力項や遠心 力・摩擦項等を補償するために, マニピュレータから観 測した位置・速度情報を運動方程式に代入し，計算して 得たトルク値をとのまま駆動のために用いると共に，慣 性に対する補償については，慣性行列からなる直列ゲイ 
ンを制御ループの中に前向きに插入する特徽がある.

この時, 慣性行列はマニピュレータの各軸の位置の関 数であるため, 慣性の変動に併せて直列ゲインも変化す ることになる. ところが, 直列ゲインの変化は位相変化 を伴わない，このことは位相進み遅れ補償の例を持ち出 すまでもなく，よく知られていることである，一方，分 解加速度制御がこの強みを発揮するのは既知の慣性変動 に対してのみであり，未知の変動には無力である.

以上，外乱オブザーバは既知・未知を問わず慣性変動 を補らように作用するが，既知変動に対しては他の制御 法が有利な場合もあることを示した。

\section{6. 低剛性かつ慣性変動を伴うロボットの特性}

実際のロボットでは，姿勢変化に際して慣性のみが変 動することはまれであり，慣性の增大と共に機械剛性が 低下する場合が少なくない，そこで周波数特性の実測例 を用いて比較検討することにする．本例で用いたロボッ トマシピュレータは， AC サーボモータを搭載した 6 軸 垂直多関節ロボットである（最大リーチ約 $860 \mathrm{~mm}$, 重 量 $120 \mathrm{~kg}$, 可搬重量は $6 \mathrm{~kg}$ ). ACサーボモータには正 弦波型の電流制御を施し，見かけ上は線形なトルク発生 器として機能するものとする．角度の検出は 1 周 4096 パルスの分解能を持つ多回転型アブソリュートエンコー ダを用い, 出力をカウンタにて計数する.

本節では，ベースに最も近い旋回軸を制御対象として, 姿勢変化に伴う周波数特性の変動を検討する.

Fig. 6 は旋回軸のモータ速度/トルク指令を実測した ものであり，Fig. 7 は先端加速度/トルク指令をロボッ ト先端に水平方向に取り付けた加速度ピックアップによ り実測したものである.

さて，Fig. 6 のAはボットが腕を延ばした時（延長 姿勢と呼ぶことにする）の旋回軸の特性である.

逆にBは腕を縮めた姿勢(基本姿勢と呼ぶことにする)

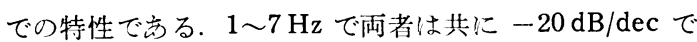

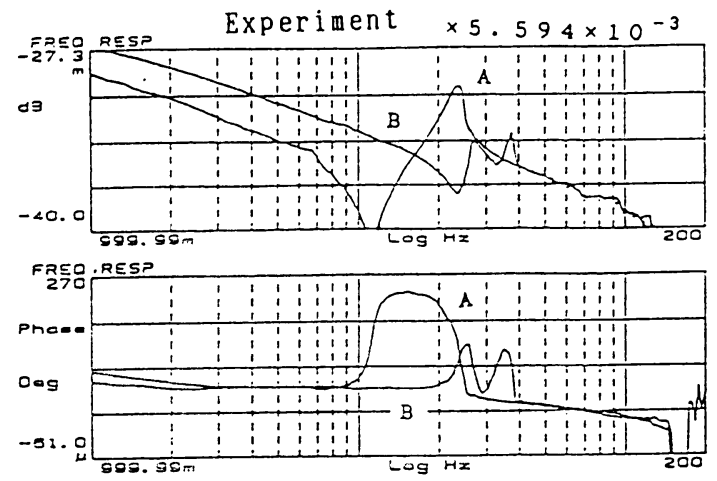

Fig. 6 Velocity at motor axis/torque

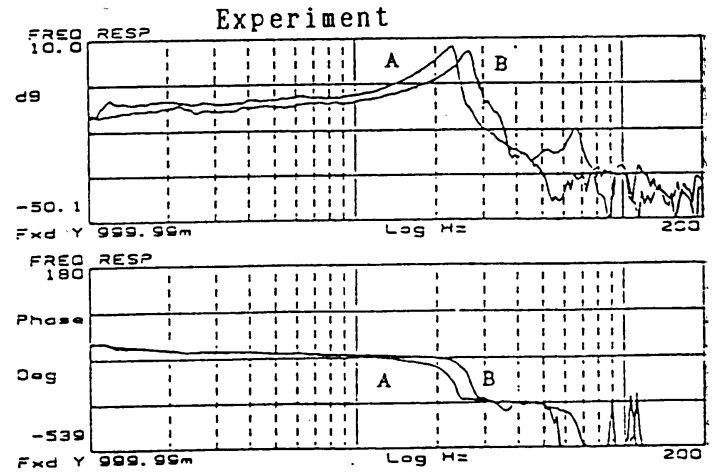

Fig. 7 Acceleration at robot/torque $A=a t$ the basic pose $B=a$ t the reached pose

直線状に下降しているが，各々は上下にずれている．位 相に関しては両者ともに -90 度付近にある.

これは慣性に関する特性 $1 / s J$ が顕著に現れる部分で あり，上下のずれは慣性の差に対応する．次にAは，11 $\mathrm{Hz}$ 付近に大きな反共振特性を持ち，位相が上昇する。 また, $22 \mathrm{~Hz}$ 付近では共振特性を持って，位相が下降し ている.この特性は 2 慣性系に特有のものであり, 制御 系にも大きな影響を与える. 一方, Bは $22 \mathrm{~Hz}$ と $32 \mathrm{~Hz}$ 付近に小さな反共振特性を持ち, $26 \mathrm{~Hz}$ と $37 \mathrm{~Hz}$ 付近に 小さな共振特性を持つ. しかしそれらはゲインが減衰し た領域にあるので無視し，慣性のみからなる特性（一20 $\mathrm{dB} / \mathrm{dec}$ の直線）に近似しても良いと思われる.

一方, Fig. 7 の先端加速度は A, B の違いに対してわ ずかに横軸方向への移動が見られるだけである．雨者共 に反共振特性は見られず，共振特性のみなので位相は共 振点付近での下降のみ生じていることが読み取れる.

\section{7. モ デル化}

振動解析の立場から考えると, 口ボットマニピュレー 夕は高次振動モードを持つ構造体である. しかし本例の 制御対象は，モータ軸に掞いてもロボット先端に打いて も 2 慣性系としての特徵が顕著であるため, 以下では 2 慣性系として制御対象のモデル化を行らことにする.

Fig. 8 は 2 慣性系に対する伝達関数ブロック図である. 式（11）の伝達関数はモータの駆動トルクを入力として, 2 慣性系の 駆動側の位置を出力とするものであり, 式 (12) は先端側の位置を出力とするものである. 本論文で は, 式 (11) を制御対象 $M(s)$ として扱う. 式の各パラ

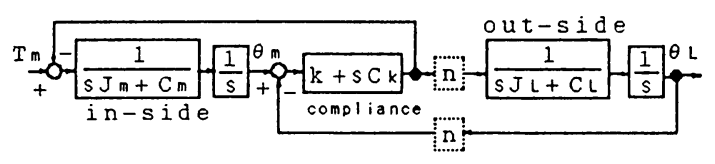

Fig. 8 Model of low-stifness plant 


$$
\begin{aligned}
& M(s)=\frac{\theta_{m}}{T_{m}}=\frac{1}{s} \frac{s^{2} E_{1}+s E_{2}+E_{3}}{s^{3}+s^{2} D_{1}+s D+D_{3}} \\
& \frac{\theta_{L}}{T_{m}}=\frac{1}{s} \frac{s F_{1}+F_{2}}{s^{3}+s^{2}+D_{1}+s D+D_{3}} \\
& D_{1}=\left(C_{L}+n^{2} C_{k}\right) / J_{L}+\left(C_{m}+C_{k}\right) / J_{m}=17.65 \\
& D_{2}=n^{2} k / J_{L}+k / J_{m}+\left(C_{m} C_{L}+n^{2} C_{m} C_{k}+C_{L} C_{k}\right) / J_{m} J_{L} \\
& \quad=2.093 \times 10^{4} \\
& D_{3}=\left(n^{2} C_{m} k+k C_{L}\right) / J_{m} J_{L}=6.682 \times 10^{4} \\
& E_{1}=1 / J_{m}=2.915 \times 10^{3} \\
& E_{2}=\left(C_{L}+n^{2} C_{k}\right) / J_{m} J_{L}=2.145 \times 10^{4} \\
& E_{3}=n^{2} k / J_{m} J_{L}=1.392 \times 10^{7} \\
& F_{1}=n C_{k} / J_{m} J_{L}, F_{2}=n k / J_{m} J_{L} \\
& \text { メータの值は, Fig. } 6 \text { の A 対してカープフィットを行 } \\
& \text { らことにより近似值として求められる. }
\end{aligned}
$$

\section{8. 外乱除去特性とロバスト安定性}

第 4 節では，Fig. 1 で表される制御系に等価変換を繰 り返すことにより Fig. 3 のように表わされることを示し

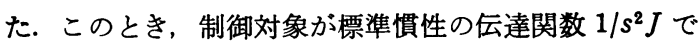
表わされるならば，制御系は PID 制御系と等価になる ことも図から読み取れることと思う。

そこで Fig. 1 の制御系から推定外乱 $T_{L^{\prime}}$ のフィード ハックを除去した制御系，すなわち PID 制御系とほぼ 等価な制御系と, 除去しない制御系とを比べた場合に, 制御対象の違いや变化に対しどのような差異が生じるの かを調べてみる.

初めに, $M(s)$ として Fig. 6 のBを伝達関数の $1 / s^{2} J$ 飞近似した場合と，Aを2 慣性系の Fig. 8 亿近似した場 合との 2 通りについて，両者の制御系の極零配置を比較 する. 具体的には「速度/外乱 $T_{L}{ }^{\prime} 」$ の極零配置をシミュ レーションにより求めて比較する.

ここで外乱 $T_{L}{ }^{\prime}$ は，本来は制御対象を $M(s)$ とおい た際の物理的な外力（トルク）とさらに残るモデル誤差 により生じるトルクとの和を意味する. しかし本節では モデル誤差はないものとし， $T_{L}^{\prime}$ を単なる外力による外 乱と考えることにする.

さて, Fig. 9 は制御対象を $M(s)=1 / s^{2} J$ として, Fig. 1 から $\theta / T_{L}{ }^{\prime}$ を求め, さらに 1 階微分したシミュレ ーション結果である. 極を -30 の 3 重極とした制御ゲ インを用いる. 当然のことながら，単なる PID 制御系 でも同じ結果を生む.

次に Fig. 10 は制御対象 A を Fig. 8 の 慣性系に近似 した場合の，PID 制御系における極零配置である. Fig. 9 で 3 重極であった 3 極は各々近くで分かれ，実軸 上の 1 つの極と 2 つの振動性の極とに変化している． ま た，虚軸付近に $2 つ の$ 零点が現れ，虚軸から離れた負の

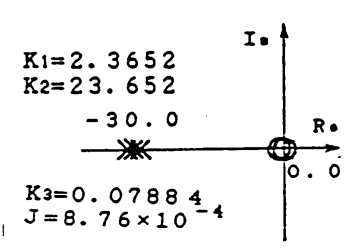

Fig. 9 Pole-zero for nominal model

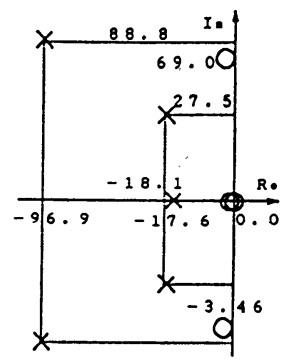

-...zero

$\times \cdots$ pole

Fig. 10 Pole-zero for lowstiffness model

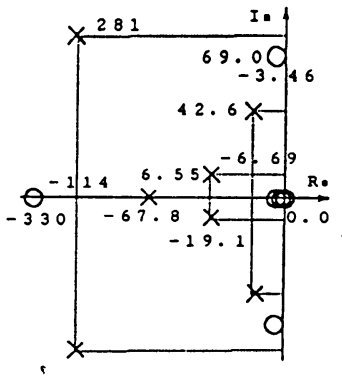

Fig. 11

With disturbance feedback (observer poles $=0.86$ )

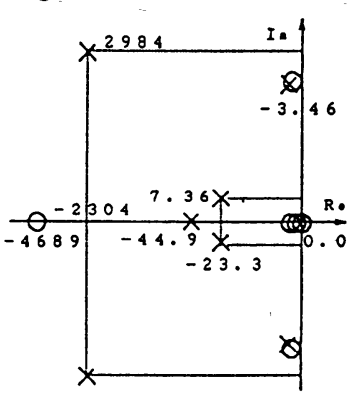

Fig. 12
With disturbance feedback (observer poles $=0.1$ )

領域に 2 つの振動極が現れている.この変化が顕著であ るため, PID 制御系では制御対象の変化に対して制御系 も大きく変化してしまうことがわかる.

Fig. 11 と 12 は，Fig. 6 のAに相当する制御対象に対 して Fig. 1 をそのまま用いた場合の極零配置シミュレー ションである. 両者はオブザーバの極のみが異なる.こ こでオブザーバ極をディジタル極で表わしているのは, 後述の実験をディジタルオブザーバにより実現している ため，それと合わせたためである（サンプリングタイム $=1 \mathrm{~ms}$ ). 前者の極は, 連続系では -150 , 後者は -2300 程度に相当する。

Fig. 10 と比較すると $3 つ に$ 分極していた原点に近い 3 極が再び-30 亿近づいている. Fig. 12 ではそれが特 に顕著である，また，虚軸付近の 2 つの零点を極零相殺 するよらに2つの極ができている，Fig.12 ではほぼ完 全に相殺している，一方，虚軸から離れた 2 極はさらに 虚軸から遠くに移されているので，実際の応答に現れに くくなっている. 以上から，これらの制御系の特性は， 見かけ上，標準慣性に対するPID 制御系に近似できる 上らに加工されているわけである.そしてこれこそが， 推定外乱のフィードベックによるモデルマッチング機能 に他ならない，また，全ての極は安定極であり，しかも モデル誤差としての外乱を除去することを示すものであ 


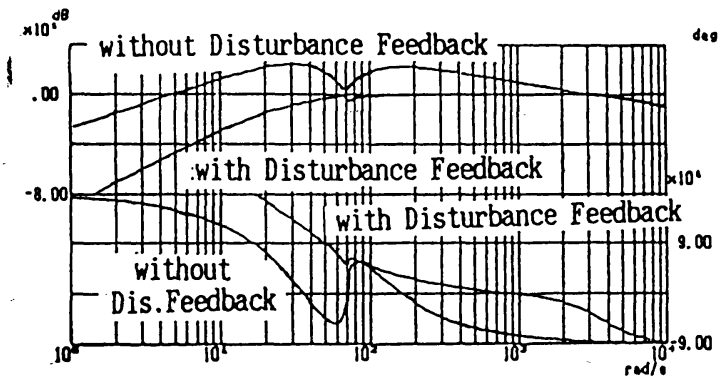

Fig. 13 Simulation of disturbance canceling for low-stiffness model

る.

次に Fig.13 の周波数特性は制御対象 Fig. 8 に対して .の制御系 Fig. 1 の「速度/外乱 $T_{L}^{\prime} 」$ 亿関するシミュレ ーション結果である.ここでは Fig. 1 亿打ける推定外乱 のフィードッックの部分を除去したものと除去しないも のとを重福きして比較できるようにしている。また， 前者は Fig. 10 と後者は Fig. 12 と等価である.

両者は共に低周波領域でのゲインが低いことから外乱 除去特性を持つと解釈できる. 但し, 推定外乱のフィー ドハックを伴う後者のゲイン曲線は周波数領域全体を通 して低いため, 広い帯域に渡って大きな外乱除去特性を 持つと考えられる. 特に Fig. 6 亿护ける零点と振動極を 前者が除去しきれないのに対して, 後者はほぼ完全に除 去している.

\section{9. 実 験 結 果}

本節では「速度/外乱 $T_{L}^{\prime}$ 」に関する周波数特性の実 測結果と台形型加測速時の速度特性の実測結果を示す.

実験で用いる外乱 $T_{L}{ }^{\prime}$ はモータ軸やマニピュレータに 值接与える外力ではなく，モー夕駆動回路へのトルク指 令に加法的に加えただけの等価外乱とする.

また，本実験のオブザーバを含む制御系は 32 ビット の浮動小数点 DSP(NEC 製 $\mu \mathrm{PD} 77230 \mathrm{~A})$ の上で, $1 \mathrm{~ms}$

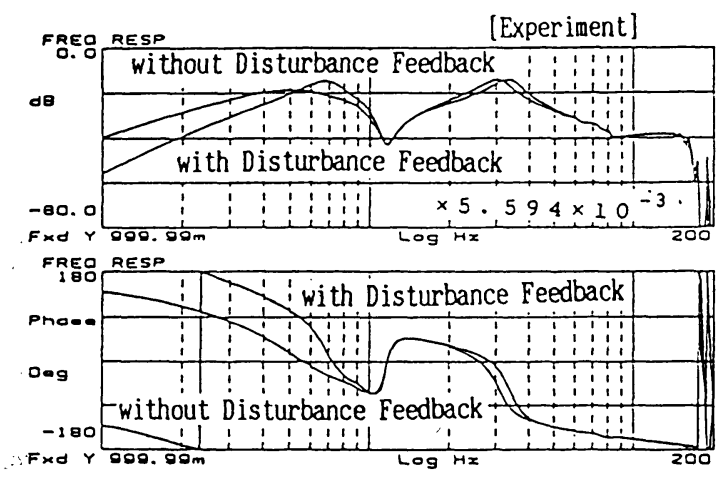

Fig. 14 Disturbance attenuation (observer poles $=0.86$ )

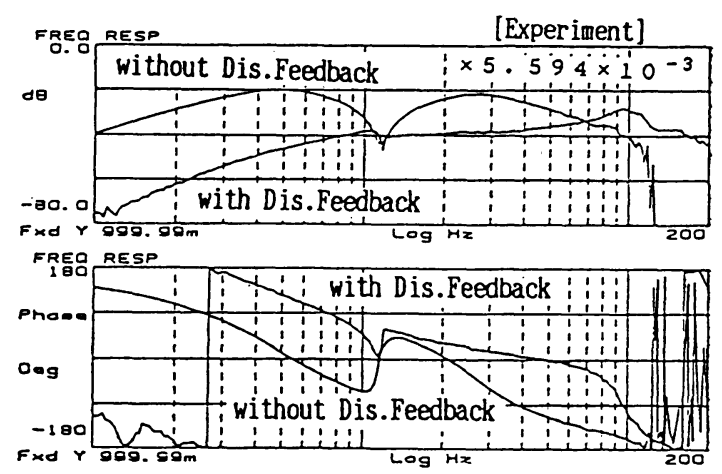

Fig. 15 Disturbance attenuation (observer poles $=0.1$ )

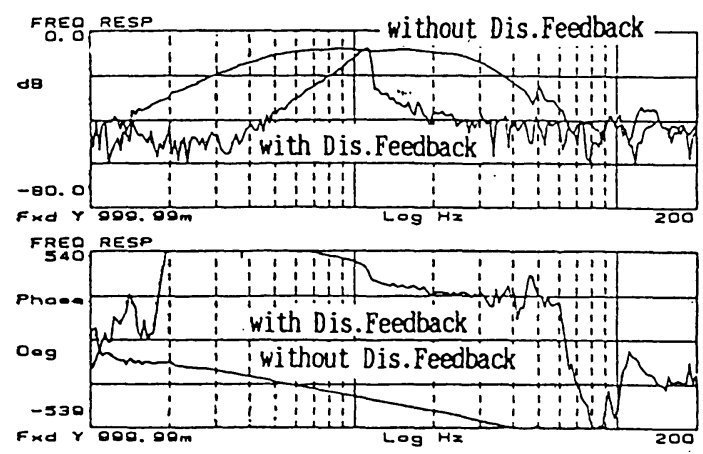

Fig. 16 Acceleration on the robot (observer poles $=0.1$ )

のサンプリングタイムで実現している.

また，周波数特性の実測には HP 製の FFT アナライ ザ $3562 \mathrm{~A}$ を用いた。 ロボットは延長姿勢である.

Fig.14はオブザーバのディジタル極を 0.86 の重極と して, 推定外乱のフィードバックを行う場合とフィード バックを除去した場合の特性の実測結果である.

低周波領域では推定外乱を戻した方が外乱除去特性に 優れるが, $6 \sim 8 \mathrm{~Hz}$ 付近では逆転し, 以降 $10 \sim 40 \mathrm{~Hz}$ 付 近の振動特性を除去できないことがわかる.

それに対して，オブザーバ極を 0.1 の重極にした例 Fig. 15 はシミュレーション結果 Fig. 13 と極似し, 200 $\mathrm{Hz}$ 付近まで大きな外乱除去特性が見られる。なお，デ イジタル極 0.1 はサンプリングタイムが $1 \mathrm{~m} \mathrm{~s}$ なの゙連 続系では -2300 程度に相当する.

次に Fig. 16 はオブザーバ極 0.1 でのロボット先端で の水平方向の加速度/外乱 $T_{L}^{\prime}$ である. 実験での外乱は モータ軸上に生じる等価外乱に限られているが，固有振 動数付近の帯域を除いて振動抑制にも寄与していること がわかる.

Fig. 17, 18,19 はモータ軸の速度とトルク指令波形の 実測結果であり，やはり推定外乱のフィードバックの有 


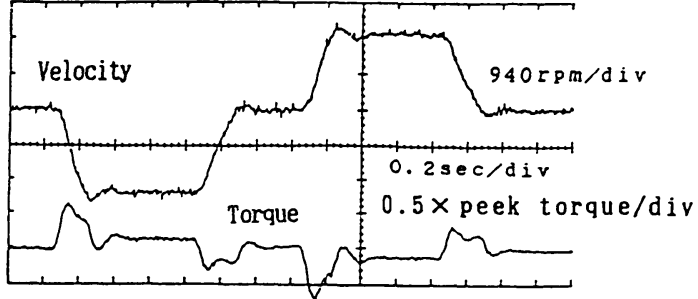

Fig. 17 Velocity and torque command without disturbance-feedback

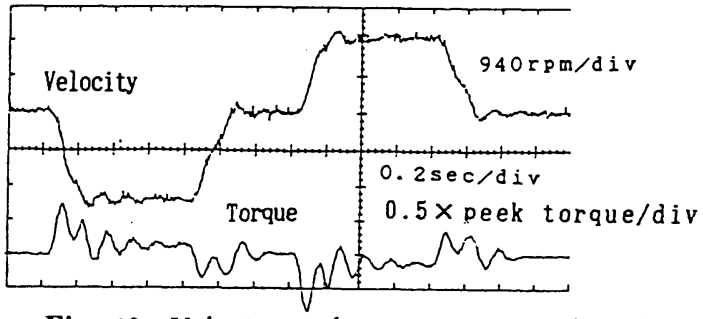

Fig. 18 Velocity and torque command with disturbance-feedback (observer poles $=0.86$ )

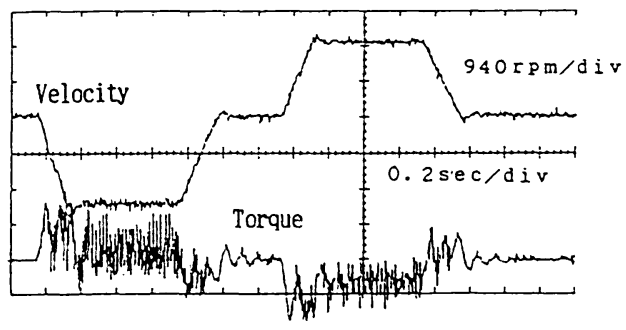

Fig. 19 Velocity and torque command w ith disturtance-feedback (observer poles $=0.1$ )

無とオブザーバ極の違いによる影響を比較するために行 ったものである，そして，台形型加減速を行うような位 置指令入力に対する応答結果である.

Fig. 17 はオブザーバ極 0.1 の条件で，推定外乱のフ ィードバックを行わない場合の特性であり,オーバーシ ニートが見られる.

Fig. 18 では推定外乱をフィードバックしているにも かかわらず，速度特性が悪化し振動的な応答波形になっ ている. 前述した通り，Fig. 18 の制御系は，Fig. 11 と も等価な制御系であり，不適切な極零配固による結果と 考えられる.

一方，オブザーバ極 0.1 を用いた Fig. 19 は，振動特 性が打ち消され，良好な速度特性が得られている。

従来, 外乱オブザーバの極零配置についてあまり言及 されることはなかったが，本例のよらな制御対象に対し， オブザーバの極零配置は重要な意味を持つと結論づけら れる.

\section{0. 結 論}

1. 位置情報と駆動トルク情報とを用いて，外乱トル クと運動速度とを同時に推定するオブザーバを紹介した。 本オブザーバの推定値は, 物理的には, 推定外乱トル クに関しては実外乱に 2 次のローパスフィルタを挿入し たものと等価であり，推定速度に関しては遅れのない実 速度を推定し，それに実外乱の変化が誤差として影響す ることを示した.

2. 加法的な外乱を定義したにすぎない外乱オブザー バが末知の制御対象モデルにどのように作用するのかを 等価変換により可視的に表し，そのモデルマッチング機 能を検証した。

3. 口ボットの慣性変動に対して，外乱オブザーバが 行うモデルマッチング機能の限界が位相変化によるるの であることを示した。

4. 慣性変動と共に剛性の低下するロボットマニピュ レータに対して，オブザーバを用いた制御系の安定性と 外乱除去特性を極䨌配置と周波数特性から説明した. 特 に周波数特性については, シミュレーションのみでなく， 実測により検証した. この結果, 本論文に拈ける制御系 は, 制御対象の持つ振動を引き起こす要因を打ち消すた めに，極零相殺あるいは極の負方向への移動を行うよう に作用し，結果的にモデルマッチングを行う働きがある ことを示した.

但し，極零相殺については安定零点に対しては有効で あっても，不安定需点に対しては不安定な極による相殺 を行う可能性があり，その結果として不安定なコントロ 一ラを実現する危険性を持つことが知られている．従っ て，外乱オブザーバの適用範囲には，制限が生じること も予想される。

5. 低剛性なロボットマニピュレータに対して外乱ト ルク・速度推定オブザーバを用いた制御系を構成する場 合, オブザーバは適切な極零配置を必要とすることを周 波数特性と速度の実測により明らかにした。 また，モー 夕軸に関する振動抑制制御であっても，口ボットの先端 の振動に対して，振動抑制効果があることを示した.

\section{謝辞}

外乱オブザーバを始めとする制御技術全般について， 機会ある度に適切な助言・ご指導を頂いている慶応大学 理工学部の大西公平助教授に感謝します.

\section{参考 文 献}

1）大石, 大西, 宮地：「状態観測器を用いた他励直流機の 一制御法」, 電気学会, 昭 59.6 .

2）湯井，大西他：「オブザーバを用いたねじり振動抑制制 
御」SICE '86.

3) 大西公平:「メカトロニクスに拈ける新しいサーボ技術」 電気学会論文誌 D 107 巻 '88.10.11.

4）駒田・大西：「関節の加速度 コントローラによるロボッ トのモーションコントロール」日本ロボット学会誌, Vol.8, No.3.

5) 堀 洋一: 「加速度制御型サーボ系」, 電気学会論文誌 D 108 巻 7 号 '87.11.2.

6)梅野・堀 :「2 自由度ロバストサーボ 系の構成とマニピ ニレータの運動制御への応用」電気学会論文誌D, Vol. 110, No.11.

7）加来, 美多他：「安定化ディジタル逆システムとその電 動機制御系への応用」電気学会産業計測制御研究会IIC89-23

8）金子, 鈴木, 谷江, 大西:「減速機付DCモータのトルク 制御, 第8 回日本ロボット学会学術講演会 '90.11.2.

9）吉田，山田，薮田：「外乱補償制御を用いた Computed Torque Method の安定性に関する一考察」第 8 回日本 ロポット学会学術講演会 '90.11.3.

10）島田 $\cdot$ 横島 $\cdot$ 渡辺・塩田・梅田 $\cdot$ 川和田 - 長井 :「垂 直
多関節 DD ロボットのディジタル制御」第 32 回自動制 御連合講演会 '89.10.4.

11）島田：「オブザーバを用いた 低剛性負荷の振動抑制制御 と特性解析」第 32 回自動制御連合講演会 '89.10.6.

12) A. Shimada, et al.: Motion Control for Vertical Type Direct Drive Robot Manipulator (IEEE International Workshop on Advanced Motion Control '90/3/29)

13）島田:「最新メカトロニクス制御技術」機峨設計 6 月臨 時増刊号 (日刊工業新聞社) '91.6.20.

14）島田：「外乱トルク・速度推定オブザーパの特性解析」 第 9 回日本ロボット学会学術講演会 '91.11. 29.

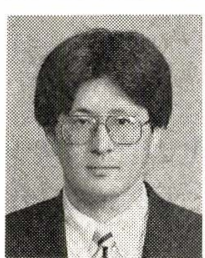

\section{島田 明 (Akira SHIMADA)}

1958 年 9 月 20 日生. 1983 年電気通信 大学電子工学科卒業. セイコー電子工業 (株)入社. FA システム部所属. ロボット コントローラ開発に従事し, 運動制御等を 担当. 日本ロボット学会, 計測自動制御学 会, 電気学会会員.

（日本ロボット学会正会員） 